\title{
Developing Scientific Approach Based Learning Module in Plantae Concept
}

\author{
$1^{\text {st }}$ Ahmad Yani \\ Biology Department \\ State University of \\ Puangrimaggalatung Sengkang \\ Wajo, Indonesia \\ ahyan_yani@yahoo.com
}

\author{
$2^{\text {nd }}$ Suradi Tahmir \\ Biology Department \\ State University of Makassar \\ Makassar, Indonesia
}

\author{
$3^{\text {rd }}$ Muhiddin \\ Biology Department \\ State University of Makassar \\ Makassar, Indonesia
}

\begin{abstract}
This study is a research and development (R\&D) which refers to 4-D development model. The objective of this study is to produce a valid, practical, and effective scientific approach-based learning module in Plantae concept. The study employed descriptive qualitative and descriptive quantitative approaches. The material experts validated the prototype 1 . The prototype 11 was tested by using the experiment design of pretest and posttest only to examine the practicality level and effectiveness of Biology learning module developed at SMAN 2 Sengkang in class X MIA 1 of academic year 2015/2016. The result of the study revealed that the scientific approach based learning module was confirmed as valid. The practical level valued from the implementation of learning which used scientific approach-based learning module was in the high category. The effectiveness of module valued from the teacher's ability in managing the learning was in a proper category, the result of students' response was $94.61 \%$ which had the good response and students' learning result improved from 35.65 to 84.35 with completeness percentage by $94.11 \%$. Thus, the conclusion of the study was the scientific approach-based learning module developed in Plantae concept was valid, practical, and effective to be used in Biology lesson.
\end{abstract}

Keywords-4-D development model, plantae concept, senior high school

\section{INTRODUCTION}

As the world paradigm in education changes, people are faced with many challenges. One of which is how to produce highly competent human resources. In line with that, Morocco asserts that education in the 21 st century requires students to master four learning competencies including good comprehension skills, critical thinking skills, collaborative skills as well as communicative skills. Referring to the competencies, the minister of education has come up with some breakthrough ideas so that Indonesian graduates have the ability to catch up with the global competition in the future. One of the examples is to implement curriculum 2013 which is oriented to create productive, creative, innovative, and effective learners through the integration of cognitive knowledge, skills, and attitudes [1].

The curriculum is applied by training students' process skills through learning activities [2]. Practically, curriculum 2013 should be implemented in a classroom where the integrated scientific and thematic approach dominates the learning activities. Students' process skills that should be improved cover the act of observing, questioning, collecting data, associating data, and communicating the results $(5 \mathrm{M}$ learning). These activities are packaged in an approach called the scientific approach [3].

However, there are a number of barriers to implementing this curriculum. This issue is strongly related to the fact that the curriculum is influenced by various aspects of the education system including the instrumental, process, or environmental input. In other words, the challenge can be associated with the teachers, time allocation, technology and communication development, learning materials, assessment process, and teaching strategies [4].

Teachers are expected to be able to provide students with appropriate learning materials to achieve the learning objectives through the scientific approach. The teachers can develop their learning materials based on the students' needs. This effort enables the students to learn a competency systematically and in an integrated way. Learning materials are also able to improve students' creativity. Therefore, teachers are required to develop learning materials through which students can explore their potentials and help themselves to be more active and creative [5].

The ministry of education has provided the learning materials of curriculum 2013. They have been available in the form of students' book, teacher's book, and assessment manual. Still, teachers need to develop the materials so that students can understand something from various perspectives. In contrary, to the primary purpose of the curriculum that is to produce graduates who are critical, creative, and have different perspectives. In addition, to prevent that condition to happen, a learning module can be developed to provide an opportunity for the students to promote their autonomous learning by not depending too much on the teachers [6].

Based on some interviews conducted to the tenth graders of SMA Negeri 2 Sengkang in 2014, it can be concluded that learning module can assist students in learning if the format could be varied concerning materials and exercises included in the module. They admitted that the presentation of the module was sometimes unsuitable with the conditions of the students. Therefore, teachers need to recreate a new module which can function as guides for the students to discover concepts in one discipline such as biology. One of the innovation could be the scientifically based module. Some studies have shown that science-based learning has a positive 
effect on students' achievement and mastery of scientific skills [7-9].

One of the subjects to teach in a biology class is Plantae which teach students to recognize the morphological properties of the plants and metagenesis on planet Earth. This subject is taught in grade X. Even though the subject is often considered complicated, students need to learn how to understand the materials in a way that is simple and compatible with their level of thinking. In SMA Negeri 2 Sengkang, the students have been using a module that is not yet able to train their critical thinking and additionally, their problem-solving skills. Besides, it has not facilitated learning with a scientific approach.

The problems stated earlier have offered a basis for the development of a learning module. This study, therefore, aimed to generate a learning module which can help students better understand concepts in Plantae. Furthermore, this module is expected to be valid, practical, and effective especially to provide learning with scientific approach which suits learners' conditions and curriculum requirements

\section{METHODS}

This research belonged to a research and development study which aimed to develop a scientific approach based learning model. It employed the 4-D research model suggested by Thiagarajan. This research model covers a series of development stages which are systematic and detail covering the defining design, develop, and disseminate. The tryout of the product was in the form of a scientifically based learning module implemented in a biology class of SMA Negeri 2 Sengkang, Kecamatan Tempe, Kabupaten Wajo. The participants of the try out were the students of X MIA 1 registered in the academic year of 2014/2015. The quality of the module was measured by assessing these following aspects: (a) validity which was measured by an expert in materials development; (b) practicality which was assessed through an observation on the implementation of the module in the classroom; and (c) effectiveness which was determined based on the results of an analysis of students' cognitive achievement, teacher's ability to organize learning and students' responses towards the feasibility of the module. Data were analyzed using a technique proposed by Hobri [10].

\section{RESULTS}

\section{Research findings}

This research and development study was conducted according to the 4-D model which consists of these four following stages: define, design, develop, and disseminate.

\section{1) Define}

This stage aims to describe and determine learning requirements. It covers analysis of students' needs, learning objectives, task assignment, and learning specification. The results of the interview revealed that:

a. The biology teachers in SMA Negeri 2 Sengkang were not familiarized with curriculum 2013 as well as the scientific approach. It has been proven by the fact that they only applied the scientific approach during a practicum.

b. The students were not able to ask questions. In fact, there were only 3-5 students who were confident enough to raise an issue to discuss.

c. The students' ability to communicate ideas was still limited.

d. Learning materials were not adequately packaged based on the students' development.

e. The teachers were only a medium to transfer information from the textbook to the students.

f. The school did not provide sufficient resources for the students to learn biology such as textbooks/reference books.

After defining the problems, a needs analysis was conducted to figure out the students' background knowledge, language, and cognitive development. The results of the analysis showed that the tenth-grade students of SMA Negeri 2 Sengkang Wajo Capital had already studied biodiversity subject in the first semester and classification of living things in junior high school. This knowledge was believed to be able to support them to understand materials developed on Plantae subject. It was found that most of the students used Bugis Sengkang language on a daily basis and Indonesia Language to interact with their friends and teachers at school. The results of a concept analysis suggested learning which referred to the curriculum applied in SMA Negeri 2 Sengkang. The students were assigned into some heterogeneous groups to conduct learning using the scientific approach, especially the "Let's Try" part that was present in the module. This task could facilitate the students to observe, ask, collect information, associate the information, and communicate it. Each section was complemented with a review test to examine the completeness of the learning objective.

\section{2) Design}

This stage comprised of three following steps. They were (1) the selection of learning resources which suit learning objectives, (2) the selection of materials presentation which covers the introduction part, materials (content), and the final part, (3) the development of prototype I.

\section{3) Develop}

The scientific approach based learning model developed was validated by two experts in material development. Aspects that were going to evaluate: (1) the appropriateness of the component and characteristics, (2) the appropriateness of the elements of quality, (3) the appropriateness of the $5 \mathrm{M}$ learning, (4) the appropriateness of the content/matter. The results of the validation proved that the module contained nonuniform fonts, unclear pictures or images, unclear explanations of the pictures or images, misused terms, inappropriate typing space, and incorrect spellings. Besides, the 5M learning activities were not systematically arranged, and the assessment part was not fully developed. More detailed validation results are presented in Table 1. 
Table 1. presents that all the components are categorized as "Valid" $(4 \leq \mathrm{Va}<5)$. Based on the validity criteria, it can be concluded that the module developed was valid and feasible. Some components, however, still required revisions.

The practicality of the module was determined after the product was tested out to some students in SMA Negeri 2 Sengkang. The intended operational of learning using the module was observed thoroughly. In general, the results of the observation are recorded in Table 2.

Table 1. The Results of Experts Validation

\begin{tabular}{|c|c|c|c|c|c|c|}
\hline No. & Aspects & Validator I & Status & Validator II & Status & $\begin{array}{c}\text { Average } \\
\text { Scores }\end{array}$ \\
\hline 1. & $\begin{array}{c}\text { The appropriateness of the component } \\
\text { and characteristics }\end{array}$ & 4,61 & Valid & 4,06 & Valid & 4,33 \\
\hline 2. & $\begin{array}{c}\text { The appropriateness of the elements of } \\
\text { quality }\end{array}$ & 4,77 & Valid & 4,15 & Valid & 4,46 \\
\hline 3. & The appropriateness of the $5 \mathrm{M}$ learning & 4,27 & Valid & 4,00 & Valid & 4,14 \\
\hline \multirow[t]{2}{*}{4.} & $\begin{array}{l}\text { The appropriateness of the } \\
\text { content/matter }\end{array}$ & 4,83 & Valid & 4,00 & Valid & 4,42 \\
\hline & Average scores & 4,60 & Valid & 4,05 & Valid & 4,34 \\
\hline
\end{tabular}

Table 2 . The results of the practicality analysis

\begin{tabular}{cccc}
\hline No & Aspects to observe & Average scores & Categories \\
\hline 1. & Steps of Learning & 4,75 & High \\
2. & Social Interaction & 4,06 & High \\
3. & Principles of Reaction & 5,00 & Very high \\
\hline & Total Score & $\mathbf{4 , 6 0}$ & High \\
\hline
\end{tabular}

Based on the results, it can be concluded that the practicality of the module was categorized very high with the average score of 4 . 60. The analysis of the module effectiveness was conducted by evaluating these following indicators: (1) the ability of the teacher to organize learning, (2) the students' responses, (3) the students learning achievement. The results of the analysis are explained as follows.

a. The teacher was able to organize learning using the scientific approach based module. Table 3 depicts the results of the analysis of the teacher's ability to organize learning.

Based on the results presented in Table 3, it can be concluded that the teacher could manage to learn with scientific approach pretty well. The teacher could achieve 3,52 (NKG/teacher's competence score) to prove that his/her competence was right $(3 \leq \mathrm{NKG}<4)$.

b. The module developed fulfilled the criteria for an effective module. The results of the analysis of the students' responses towards the implementation of the module are presented in Table 4.

Table 4. shows that the module was effective. There were $94,61 \%$ of the students providing positive responses: $98,04 \%$ of the students strongly agreed, $91,18 \%$ agreed, and $10,78 \%$ entirely agreed.

c. There were 34 students involved in this study. They were heterogeneous concerning cognitive, and most of them did not have access to reference books so the library was the only place from where they can borrow books. Before the implementation of the module, the pretest was conducted to measure their comprehension of the Plantae subject. The post-test was executed after the treatment to investigate the students' achievement. The test consisted of 25 multiple-choice items with five alternative answers. The results of the test are depicted in Table 5.

It can be concluded that the students achieved better in Plantae after the implementation of the module. There were $94,11 \%$ of the students able to get a higher score on average.

\section{4) Disseminate}

At this stage, the module had been revised, validated, and tried out. Therefore, it was ready to disseminate to the higher scale of participants such as to other groups of students, teachers, or schools. A socialization program was held to familiarize teachers in SMA Negeri 2 Sengkang with the learning module. The learning module was introduced to the teachers. As a result, this module was proven to be able to meet the standards of content, presentation by giving full attention to the rules of writing a module and biology materials development. 
Table 3. The Results of the Analysis of Teacher's Ability to Organize Learning

\begin{tabular}{llcl}
\hline No & Aspects to observe & Average Scores & Categories \\
\hline 1. & Pre-teaching activities & 3,89 & Good \\
2 & Whilst teaching activities & 3,50 & Good \\
3. & Post activities & 3,50 & Good \\
4. & Classroom condition & 3,31 & Good \\
\hline & Total Score & $\mathbf{3 , 5 2}$ & Good \\
\hline
\end{tabular}

Table 4. The Results of the Students' Responses

\begin{tabular}{ccccccc}
\hline \multirow{2}{*}{ No } & Aspects & \multicolumn{5}{c}{ Responses } \\
\cline { 3 - 7 } & & $\mathbf{1}$ & $\mathbf{2}$ & $\mathbf{3}$ & $\mathbf{4}$ & $\mathbf{5}$ \\
\hline 1. & Clarity & - & - & - & $48,04 \%$ & $51,96 \%$ \\
2. & Compatibility with 5M & - & - & $6,86 \%$ & $52,94 \%$ & $40,20 \%$ \\
3. & Presentation & - & - & $3,92 \%$ & $38,24 \%$ & $57,84 \%$ \\
\hline \multicolumn{2}{c}{ Total } & - & - & $\mathbf{1 0 , 7 8 \%}$ & $\mathbf{9 1 , 1 8 \%}$ & $\mathbf{9 8 , 0 4 \%}$ \\
\hline gloss 1: Strongly disagree (-) 4: Agree (+) & & & & &
\end{tabular}

2: Less Agree (-) 5: Strongly Agree (+)

3: Quite Agree (-)

Table 5. Statistical Analysis of Students' Achievement

\begin{tabular}{lccc}
\hline & & & Achievement \\
No. & Notes & Pretest & Posttest \\
\cline { 3 - 4 } 1 & Pass & 3 & 32 \\
2 & Fail The Percentage of Students who & 31 & 2 \\
3 & Passed & 8.82 & 94.11 \\
4 & Total Score & 1.212 & 2.868 \\
5 & Average Scores & 35.65 & 84.35 \\
6 & Lowest Scores & 20 & 68 \\
7 & Highest Scores & 76 & 96 \\
\hline
\end{tabular}

\section{DISCUSSION}

\section{Description of the module components}

One of the influential factors that affect learning is learning materials such as learning modules. Learning modules help teachers to organize learning better and assist learners in achieving the learning objectives. In line with the cognitivism theory of learning, students are required to activate all their senses to acquire knowledge. The activation of the senses can be done using a medium or a method [11].

The components contained in the module developed on the Plantae subject are described as follows.

a. The outside cover of the module is made of stiff paper and laminated so that the content can be protected while the inside cover is made of a 70 gr paper. Some information about the module is written on the cover. The information covers the identity of the module such as (1) the title "Biology Module", (2) the target readers, "for SMA grade X semester II", (3) the name (s) of the author (s), (4) The approach used "Scientific Approach", (5) the concepts taught, "Plantae". The identity is supported by pictures to make the module appealing to the students.

b. The acknowledgment is written to help express the author (s) gratitude upon the completion of the module. Besides, it also informs the readers about the purpose of developing the module, the significance of the module, and the opportunity to provide suggestions.

c. Table of content consists of the titles, subtitles, and the page numbers.

d. The introduction part contains the description of the module, the information that the module should be used by the students to learn in the classroom, a concept map, guidance to use the module, core of competence, the standard of competence, and learning indicators. 
e. The materials are broken down into some small units. Each unit contains learning objectives. To achieve the goals, the students need to conduct $5 \mathrm{M}$ learning. There is also a summary and evaluation provided at the end of each unit.

f. The bibliography contains all books to which the author (s) referred to while writing the module.

Plantae materials are covered by learning activities 14. Each part starts with the "Let's Try" part which requires the students to observe, ask, experiment, associate, and communicate. These activities are the distinctive features of this learning module.

\section{The validity of the module}

Theoretically, this module was validated by one expert in materials development and one expert in Biology. The module was evaluated based on these following criteria: (1) the appropriateness of the component and characteristics, (2) the appropriateness of the elements of quality, (3) the appropriateness of the 5M learning, (4) the appropriateness of the content/matter.

The validation process was referred to what Daryanto suggested about the characteristics of a module [5]. A functional module is the one that can improve students' motivation by promoting these features: self-instruction, self-contained, stand-alone, adaptive, and user-friendly. This module, therefore, was considered valid since it contained the elements of a qualified module such as good materials organization, appropriate fonts used, and its consistency.

The module was considered valid since it helped promote the $5 \mathrm{M}$ learning. The module has provided clear respond positively to learning, it means that the objectives have been achieved [10].

The results of the tests proved that the module had a significant effect on the students' achievement. It was found that $94,11 \%$ of the students improved their mastery of Plantae subject after the implementation of the module in their classroom. This result is similar to the results of the previous study which have proven the effectiveness of the scientific approach in improving students' achievement and basic science skills [12].

\section{CONCLUSION}

Based on the results of this research, it can be concluded that: 1) this learning module has reached a high score invalidity that is 4,$34 ; 2$ ) the practicality level of the learning activities conducted using this learning module is 3,65 which is considered high; 3 ) the effectiveness score of the learning module is 3,52 which belongs to the good category with an interval $3 \leq \mathrm{NKG}<4.94,61 \%$ of the students have provided positive responses, and $94,11 \%$ of the students have improved their mastery level on Plantae subject. The average score for the improvement is 48,70 . instructions for the students to do an observation. This part of the module presents detailed information since it also displays some picture and images to help the students to understand the process. This result is following the statement of Kemendikbud that says that students can read, listen, and watch their surrounding to observe [2]. To conclude, this module was categorized "Valid" $(4 \leq \mathrm{Va}<5)$ with the average score of $\bar{V}=4,34$.

\section{The practicality of the Module}

The effectiveness of the module was concluded from the results of an observation of the learning process management, an analysis of the students' responses towards the implementation of the module, and the students' achievement. The ability of the teacher to organize learning was one of the influential factors that affected the learning success. The learning activities covered pre-teaching, while teaching, and post-teaching activities. The pre-teaching activities were aimed to prepare an effective learning situation which enabled the students to study well. The main purpose of the pre-teaching activities based on the scientific approach is to relate the students' background knowledge to new information that they are going to acquire.

The student's responses towards the module were collected by a questionnaire. The results of the analysis of the questionnaire showed that almost all the students provided positive responses towards the implementation of the module. The students perceived the approach as something new since the module they used to use did not encourage them to think critically and to apply their knowledge. According to Hobri, if $80 \%$ of the students

\section{ACKNOWLEDGMENT}

We would like to express our gratitude to the people who have been involved in this study including:

1. The Directorate of Higher Education

2. The Director of Graduate Schools of Universitas Negeri Makassar

3. The Advisers and The Head of Biology Department, Graduate Schools of Universitas Negeri Makassar.

4. The Principal and Teachers of SMA Negeri 2 Sengkang Wajo Regency South Sulawesi

\section{REFERENCES}

[1] Hosnan, M., Pendekatan Saintifik dan Kontekstual dalam Pembelajaran Abad 21, Jakarta: Ghalia Indonesia, 2014.

[2] Kemendikbud, Materi Pelatihan Guru Implementasi Kurikulum 2013, Jakarta: Kemendikbud, 2013.

[3] Majid, A., Implementasi Kurikulum 2013 Kajian Teoritis dan Praktis, Bandung: Interes Media, 2014.

[4] Abidin, Y., Desain Pembelajaran dalam Konteks Kurikulum 2013. Bandung: Refika Aditama, 2014.

[5] Daryanto, Pendekatan Pembelajaran Saintifik Kurikulum 2013, Yogyakarta: Gava Media, 2014.

[6] Depdiknas, Panduan Pengembangan Bahan Ajar, Jakarta:Depdiknas, 2008 .

[7] Fauziah, Pendekatan Saintifik Pembelajaran Elektronika Dasar Melalui Model Pembelajaran Berbasis Masalah, http: //repository. 
upi. edu /3226/2 / S_TE_0905748_ Abstract.pdf. Accessed date: 20 September 2014.

[8] Mulyono et.al., "Pengembangan Perangkat Pembelajaran dengan Pendekatan Sainctific Skill Teknologi Fermentasi Berbasis Masalah Lingkungan,” Lembar Ilmu Pendidikan, vol. 4(1), pp. 20-26, 2012.

[9] Sawitri et al., "Pengembangan Modul Keanekaragaman Hayati Berbasis Pendekatan Saintifik untuk Peserta didik Kelas X SMA, Bio Edu,vol. 3(3), 2014.

[12] Sunck. D, H., Learning Theories an Educational Perspective, Yogyakarta: Celeban Timur, 2012.
[10] Hobri, "Metodologi Penelitian Pengembangan (Developmental Research) Aplikasi pada Penelitian Pendidikan Matematika)," Program Pendidikan Matematika FKIP Universitas Jember, 2009

[11] Sani, R., Pembelajaran Saintifik untuk Implementasi Kurikulum 2013, Jakarta: Bumi Aksara, 2014 